\title{
En solskinnshistorie
}

President Barack Obama signerte 23.3. 2010 lovene som vil reformere helsevesenet i USA. Dypt begravet i den omfattende lovgivningen finnes en lov som foreløpig ikke har fått så mye oppmerksomhet, men som vil få stor betydning for leger og legemiddel- og utstyrsindustrien: the Physician Payments Sunshine Act (1). Loven krever at alle amerikanske bedrifter som produserer legemidler, utstyr, reagenser m.m. som brukes i helsevesenet, må rapportere absolutt alle bidrag til leger og sykehus til en offentlig tilgjengelig database. Vi snakker da om alt som overstiger 10 amerikanske dollar i verdi. Alle slags bidrag er omfattet: gaver (inkludert penner og post it-blokker), honorarer, ulike former for utgiftskompensasjon, reisebidrag, måltider, forskningsstøtte og stipender, støtte til kurs og møter - og selvsagt slikt som aksjer, medeierskap og patentrettigheter. Kort sagt alt som på amerikansk benevnes som «transfer of value». Det vil kreves detaljert rapportering av både legen(e)s navn og adresse samt overføringens verdi, dato og hvordan den ble gitt eller kompensert. Og dersom betalingen er knyttet til markedsføring, foredrag, kurs eller forskning knyttet til et bestemt produkt, må produktets navn rapporteres. Alt - smått og stort - skal nå offentliggjøres.

Den nye amerikanske lovgivningen er presset frem av en stadig økende tverrpolitisk skepsis til konsekvensene av de store økonomiske overføringene mellom kommersielle aktører og leger og forskere. Anslagsvis 30 millarder dollar per år brukes til ren markedsføring av legemidler bare i USA. Utgiftene til reseptbelagte legemidler ble femdoblet i perioden 2000-05. Men detaljeringsgraden $i$ the Physician Payments Sunshine Act og at det som tidligere har vært regnet som ubetydelige små gaver skal rapporteres, vil nok komme som en overraskelse på mange amerikanske leger. Det gir også grunn til ettertanke for oss.

Det er flere forhold som har medvirket til den nye lovgivningen. For det første er det noen svært stygge saker der toneangivende leger og institusjoner har fått millioner av dollar fra legemiddelog utstyrsprodusenter for å bruke og å anbefale deres produkter. For det andre er omfanget av interaksjoner mellom leger og industri stort: $94 \%$ av amerikanske leger oppgir å ha mottatt noe fra industrien siste år (2). For det tredje følges ikke alltid nåværende retningslinjer om å oppgi potensielle interessekonflikter. En studie som nylig ble publisert i New England Journal of Medicine, viste f.eks. at bare $70 \%$ av den faktiske finansieringen av foredragsholderne ved det årlige møtet til American Association of Orthopedic Surgeons i 2008 ble rapportert - til tross for temmelig klare retningslinjer (3).

Like viktig er en erkjennelse av at også små, tilsynelatende bagatellmessige, gaver og tjenester skaper uheldige bindinger som påvirker medisinske beslutninger. Inntil nylig har de fleste betraktet små gaver som harmløse og ansett dem som en del av en hyggelig og nyttig faglig dialog mellom produsenter og brukere av legemidler og medisinsk utstyr. Også Legeforeningens egne retningslinjer for samarbeid og samhandling mellom leger, foreningen og legemiddelindustrien reflekterer dette synet. Men ny forskning viser at selv bagatellmessige gaver påvirker atferden til mottakeren på måter som man sjelden er seg bevisst, blant annet gjennom helt basale, menneskelige reaksjoner på gaver: Man ønsker å gi noe tilbake til giveren (4-6).

The Physician Payments Sunshine Act legger ingen restriksjoner på samarbeid mellom leger og industri. Den krever bare at alle former for samhandling og utveksling av gaver og tjenester gjøres helt åpent. Det er ingen tvil om at etterlevelse av loven vil bli både tidkrevende og tungvint, men samtidig vil rapporteringen bli mer enhetlig og helhetlig.

Mer enn noe annet er vi som profesjon avhengig av tillit. Det gjelder her hjemme i like stor grad som i USA. I USA har det vært større pengesummer involvert og større skandaler på dette området enn vi foreløpig har sett i Norge. Disse sakene har gitt grobunn for en ganske omfattende mistillit til at leger ikke er så uavhengige av kommersiell påvirkning som de burde være. Men problemet - og den gryende mistilliten - er selvsagt ikke bare et amerikansk fenomen. Det er avgjørende både for pasienter, leger og samfunnet at denne mistilliten ryddes av veien. «I personally am in favor of the idea that sunshine is the best disinfectant,» sa påtroppende direktør for National Institutes of Health Francis Collins i et intervju nylig (7). På samme måte som vi som enkeltpersoner undervurderer hvordan vi påvirkes av reklame og gaver, har vi kanskje overvurdert hvor mye vi som gruppe kan oppnå med interne, etiske regler. La like godt absolutt alt komme frem i lyset!

\section{Charlotte Haug}

redaktør

Litteratur

1. H.R.3590 - Patient Protection and Affordable Care Act, section 6002. www.docstoc.com/docs/31539134/HR-3590-Patient-Protection-AffordableCare-Act/ (27.4.2010)

2. Campbell EG, Gruen RL, Mountford J et al. A national survey of physicianindustry relationships. N Engl J Med 2007; 356: 1742-50.

3. Okike K, Kocher MS, Wei EX et al. Accuracy of conflict-of-interest disclosures reported by physicians. N Engl J Med 2009; 361: 1466-74

4. Wazana A. Physicians and the pharmaceutical industry - is a gift ever just a gift? JAMA 2000; 283: 373-80

5. Iserson KV, Cerfolio RJ, Sade RM. Politely refuse the pen and note pad: gifts from industry to physicians harm patients. Ann Thorac Surg 2007; 84: 1077-84

6. Katz D, Caplan AL, Merz JF. All gifts large and small: toward an understanding of the ethics of pharmaceutical industry gift-giving. Am J Bioeth 2003; 3: 39-46.

7. Steinbrook R. Opportunities and challenges for the $\mathrm{NIH}-$ an interview with Francis Collins. N Engl J Med 2009; 361: 1321-3. 